\title{
INTERNATIONAL LEGAL STUDIES
}

\author{
JOEN B. HOWARD*
}

I N SPITE of the substantial involvement of the United States in world affairs, the law schools have only recently begun to convert their standard curriculum into one that has wider contact with the expanding realm of international problems which lawyers must face as practitioners, teachers and citizens. However, the misconception still persists in some places that international legal studies consist of a few courses in the law school curriculum designed for those specialists who will occupy a handful of positions in international organizations and companies. American legal education has not yet solved the problems of dealing with international studies, not alone as specialities for a few, but as what they are in fact: a whole new dimension or set of dimensions of the problems with which all lawyers are or should be vitally concerned.

Moreover, the law schools are engaged, along with other schools and departments on university campuses, in a vigorous effort to remedy shortcomings in American higher education. A reader of the Journal of Legal Education and of law deans' reports cannot fail to be impressed with the self-criticism among law schools on a wide range of subjects cutting across domestic and international fields: crowded curriculum, lack of research, vocational orientation, inadequate financing.

In this article I shall attempt to describe some aspects of the challenge faced by the law schools in dealing with international and foreign problems and some of the programs developed and difficulties encountered in the field of international legal studies. ${ }^{1}$ If my comments reflect the view that lawyers are a bit behind the times, this is not intended as a special indictment of lawyers. Economists, political scientists and other university colleagues of the lawyer are in similar situations. Whether or not the lawyer is further behind, his traditional role as a leader in our society is at stake.

\section{I}

Among the growing chorus of Western authorities who have voiced the need for a new approach by lawyers to international affairs, there are many refrains. Yet there is also substantial harmony; the changes that are taking place in international legal studies reflect a considerable measure of common accord.

* Director of the Ford Foundation's International Training and Research Program. The views expressed in this article are those of the author and do not necessarily reflect the opinion of the Ford Foundation.

1 This term, or the alternative "transnational legal studies" preferred by some, is used to encompass international law, comparative law, and the entire range of problems encountered by lawyers in dealing with foreign and international activities. 
This changing content may be viewed from different standpoints: the perspective of recent history, new international problems that have emerged, and a shift that has occurred in intellectual outlook.

Viewed from the standpoint of recent history, international relations have changed dramatically. In less than half a century we have witnessed two world wars, communist revolutions in Russia and China, the collapse of European empires and areas of influence in Asia and the Near East, the creation of the United Nations, and the development of nuclear weapons and intercontinental ballistic missiles. It is not difficult to agree that such catastrophic events have shattered any pre-established international order and that a new order must be created in its place. It is more difficult to perceive what the new order and the place of law in it shall be. American lawyers tend to see in the recent events "the crisscrossing of two revolutionary movements: the revolution of technology, and the revolution worked by the contagious ideas of liberty represented in our Declaration of Independence and our Bill of Rights." ${ }^{\prime 2}$ Together with their West European colleagues, American lawyers seek to find or hope to create in every free country, Western or non-Western, the common elements of an order based on the "rule of law." 3 The Soviet or communist lawyer, on the other hand, sees in recent historical events an unfolding of the scientific laws of history, the inevitable destruction of a doomed order, and the establishment of a radically new order of socialist legality. ${ }^{4}$

The emergence of international problems that are wholly new or whose magnitude is vastly greater is another aspect of the change that has occurred in international studies. The uncompromising confrontation of the United States and the Soviet Union pervades the very atmosphere in which the morning newspaper reader begins his day. Its military, political, economic and educational dimensions are probed and prophesied by experts and commentators. The underdeveloped two-thirds of the world's population, principally in Asia and Africa, present another immense range of problems and opportunities. How to achieve economic growth in a pre-industrial society, how to reconcile the welfare state and individual liberties, how to incorporate modern Western science, law and education within tribal or ancient cultures-these are questions the

2 Staley, The Future of Underdeveloped Countries 39 (1954). The quotation is a paraphrase of a statement by former Secretary of State Dean Acheson.

${ }^{3}$ See Katz, The Rule of Law as Understood in the West, and Schlesinger, The Rule of Law in Oriental Countries, $6 \mathrm{Am}$. J. Comp. Law 518 and 520 (1957), reporting on two colloquia before the International Association of Legal Science held at the University of Chicago Law School, September 8-16, 1957. See also American Council of Learned Societies, Government under Law and the Individual (1957). The International Commission of Jurists, which has issued a number of publications on the rule of law in different countries, held a conference on this subject in Delhi in January, 1959.

4 See Katz, Socialist Legality and Government under Law, Harvard Law Record (Nov. 13, 1958), reporting on the conference of the International Association at Warsaw, September 10-16, 1958. 
study of which has led to great new branches of economics, political science and sociology. Another dynamic set of phenomena for the student of international relations are the proliferation in former colonial territory of new states ${ }^{5}$ and the simultaneous counter-trends toward integration and regionalism in Europe, the Near East, Africa and elsewhere. Finally, one might mention the totally unprecedented burdens and complexities of governmental administration and multilateral diplomacy, which preoccupy the student of public administration as well as the harassed government official.

A third standpoint from which to consider the changing content of international studies is the shift, still in process, from a Western intellectual orientation to a more universal outlook. Heir principally to Western civilization, the United States has been thrust into close relations with unfamiliar Asian and African civilizations and into a position of responsibility that is incompatible with our ignorance of them. This has affected not only our foreign policy, but also our education. Great strides have been made in post-war years to build up the missing foundations of our educational establishment that are essential to support our interests and responsibilities in the non-Western areas of the world. ${ }^{6}$ Important examples are "area studies" concerning these unfamiliar areas, comparative studies of the roles of government, law and education in Western and non-Western societies, and policy-oriented studies designed to illuminate the issues that confront American foreign policy throughout the world. Instead of subordinating problems to academic disciplines, students of international affairs are focusing many disciplines on the new problems and searching for new intellectual frameworks to enlarge understanding.

The new approach in international legal studies embodies these changes. It is a practical approach to problems-problems that cut across the customary branches of international law, comparative law and conflicts of law, and across both "domestic" and "international" branches of law. The traditional emphasis in international law on relations between states is inadequate to deal with these problems. Under the new approach, a more wide-ranging attention is being given to a variety of participants including not only states, but also international organizations, transnational companies and associations of many sorts,

s In an unpublished paper Burton Marshall says the following about the new states, many of which he characterized as "fledgling states": "It is too easy to be imaginative about world authority while disregarding the failure of many of the political entities to achieve the idea of authority in their own politics; to project world law while disregarding the deficiency of the concept of law among so many of the states; to project international cooperation, while ignoring the circumstance that so many of the states have not yet matured to the idea of collaboration in their own existence. I often hear it said that the nation state is obsolete. Whatever the truth of this observation applied to the conditions of Europe, it strikes me as misleading for large portions of the world where the state has not really arrived."

- The Ford, Rockefeller and Carnegie foundations have all given substantial support to such activities. An amusing but revealing commentary on the Western orientation of American education is found in Ward, What Did Confucius Say? Animadversions on the Tribal CurricuJum, 11 J. Gen. Ed. 3 (1958). 
and individuals. The traditional subjects of the rights and duties of states in peace and war must make room for treatment of the political, economic and social factors underlying relations between states, the widespread activities of international organizations, the creation of new nations and regional organizations, and the protection of fundamental human rights. ${ }^{7}$ Hand-in-hand with the growing complexity and variety of subject matter goes the search for a new universality on which to base responsibility; despite the lawlessness of international relations, there is a growing optimism concerning legal opportunities.

A few quotations from Western authorities will serve to illuminate these genexal comments concerning the changing content of international legal studies.

The Common Law of Mankind, ${ }^{8}$ a recent book by C. Wilfred Jenks, an English international civil servant of long experience, makes several points concerning the inadequacies of traditional international law and the problems of the lawyer in the present stage of development of the international legal order. International law, as we have known it, Jenks writes, is a development principally of Western Europe, designed primarily to regulate the external relations among West European states and with the non-Western world during the few centuries of transition from feudalism to modern times. This law is inadequate to the needs of the present-day, virtually universal society of nations, with its social, cultural, economic and political differences. A less rudimentary international law, respected by such differing peoples, needs to be drawn from and based upon the legal experience of this wider society. Such a law Jenks terms the common law of mankind. He refers to the shift in intellectual interest from a Western to a world-wide perspective that is taking place in other fields such as the arts, philosophy, history and the social sciences. There is need for a comparable readjustment of perspective by international lawyers. Jenks draws from his broad experience with international organizations to write of the impact of their activities in the economic, social and cultural field upon international law. He writes realistically of the disillusionment concerning the outlook for international organization and law, of the disruptive effects of world war and the cold war, the striking destruction of the balance of power among a group of states sharing a common civilization that was one of the essential foundations of the community of international law, and of the aggravation of uncertainty and pessimism by the political character of the voting procedures in the United $\mathrm{Na}$ tions. Yet he is impressed, nevertheless, with the progress that has been made on many fronts, including the elimination of the fundamental weakness of the international law of 1914, the legality of violence; the making of new international law through the legislative activities of international organizations; and

${ }^{7}$ But compare Stone, Legal Controls of International Conflict (1954). In this excellent book Stone deplores the neglect of the law of war as a "grave disservice to humanity" insofar as that neglect is based on the illusion that "interstate conflict and war are exceptional and anachronistic phenomena" removed from scientific attention. Id., at xxxiv.

${ }^{8}$ Jenks, The Common Law of Mankind (1958). 
the development by international organizations of activities in the economic and social field, comparable in importance to the development of the administrative process in the national regulation of economic and social questions.

His central theme is well stated in the following excerpt from his book:

Among the profound transformations which international law has experienced in the course of the last century none has been more significant or far-reaching than its transformation from the law of a family of nations based on Western Christendom into the law of a universal world community-a transformation which has occurred so rapidly that we frequently fail to measure its full impact.... In deducing the law from the general principles recognised by civilised nations we can no longer confine our purview to the civil law and common law systems. Can we deduce a sufficient consensus of general principle from legal systems as varied as the civil law with its multifarious European, Latin American and other variants, the common law with its variants, Islamic law with its variants, Hindu law, Jewish law, Chinese law, Japanese law, African law in its varied forms and Soviet law to give us the basic foundations of a universal system of international law? Herein lies the heart of our contemporary problem. In an attempt to explore and clarify the matter it is proposed to consider topics selected from several major areas of the law, from the fundamentals of the law of peace, from the crucial issues in the contemporary law of international economic relations, and from the relationship of the law to human freedom and the equality of man.... From this inquiry we shall reach the conclusion that we have, in the major legal systems of the world, the elements of a universal legal order, but that a sustained effort of intellectual reorientation in all parts of the world will be necessary to create and consolidate such an order, and that political advance, economic development and the progress of international law on a universal basis are interdependent upon each other. 9

A second European writer is Judge Charles de Visscher of Belgium, a former member of the International Court of Justice. His book Theory and Reality in Public International Law, ${ }^{10}$ according to his translator, "may perhaps have launched a revolution in the study of international law."'11 Critical of the traditional school of international law, he believes that it "misrepresented reality by reducing law to nothing more than the rules evolving from agreements between States. ... Remaining ... essentially formal, it exaggerated the specificity of international law, separating it off from the moral, social and political data which form its sphere of application and condition its effectiveness." that most contemporary authors are conscious of the insufficiency of earlier methods, he urges that greater attention be paid to the realities of international relations.

De Visscher finds lacking in the international community the material and

Id., at 2-3.

${ }^{10}$ De Visscher, Theory and Reality in Public International Law (translated from the French by P. E. Corbett, 1957).
II Id., at ix.
12 Id., at xi. 
moral factors which engender the idea of law and the sense of obligation in the modern nation state:

It is in contact with the world outside that any social group differentiates and becomes conscious of itself; only against the stranger does its solidarity fully assert itself. The modern State owes its historical cohesion and strong individualization to external pressures and the sentiments of loyalty to the national collectivity that they have generated and stimulated. ...

The international community has no such decisive factor of social cohesion. It has no substitute for it save the infinitely less powerful appeal to sacrifice, to a common supranational good. And this, a perception which is the source of all progress, is hardly accessible to the immense majority of men. Nothing makes the contrast sharper than a comparison of the reactions provoked in the two orders when their essential interests are at stake. . . . 13

Historical center of national exclusivism, the State by its mere existence conduces to the intransigent assertion of sovereignty. It is therefore pure illusion to expect from the mere arrangement of inter-State relations the establishment of a community order; this can find a solid foundation only in the development of the true international spirit in men. ... What is decisive is the disposition within the State to keep its action within the limits assigned to it by a functional conception which orders power to human ends instead of dedicating it to its own indefinite extension. Relations between States cannot be isolated from the relations between man and power within the State. There will be no international community so long as the political ends of the State overshadow the human ends of power. ${ }^{14}$

De Visscher proposes a research program which would take advantage of new insights and perspectives that the study of international relations opens up to international law. ${ }^{15} \mathrm{He}$ admonishes:

The hour is not one for doctrinal generalizations moving in the rhythm of a transcendental logic, or for brilliant systematizations in which intellectual ingenuity often counts for more than respect for the facts. It is rather one that challenges us to recognize the limits which in our day the dependence of international law on the historical forms of power distribution sets to its effectiveness, and to seek in the human ends of power the moderating principle that may develop aspirations to international collaboration. . . . The individualistic distribution of power among nations has appeared to us to be, if not the sole, at least the primary cause of the present deficiencies of international law. In fact, every attempt to organize international relations is an attempt to redistribute power, and there can be no doubt that this is the way of progress. ${ }^{16}$

On this side of the Atlantic voices have likewise been raised concerning the inadequacies of international law. Philip Jessup, in a recent address, "The Future of International Law Making," "17 analyzes present challenges to the inter-

$$
\begin{array}{ll}
{ }^{13} \mathrm{Id} \text {., at } 89 & { }^{15} \mathrm{Id} \text {., at xiii. } \\
{ }^{14} \mathrm{Id} \text {., at } 92-93 . & { }^{16} \mathrm{Id} \text {., at } 365 .
\end{array}
$$

${ }^{17}$ Unpublished lecture given at a conference observing the centennial of the Columbia Law School, New York City, November 6-8, 1958. 
national order and forecasts that the advances in international law within the next century will be more extensive and more far-reaching than those which have occurred since the middle of the nineteenth century. Among new challenges to the international lawyer, Jessup lists the problems that the accomplishments of the natural scientist have opened up in areas such as the control of nuclear weapons, the polar areas and outer space; and the problems that grow out of the evolution of international organizations-entities composed of many states which have separate personalities and separate rights and duties. He states:

[J]ust as the concept of the corporation was a revolutionary notion in our private law, so the concept of the international organization as an entity separate and apart from its members can play a revolutionary part in the evolution of international law.

At the very outset this concept challenges much of the theory of international law which has been conceived of as a law between and among states.

The implications for international legal studies of such considerations are illustrated by Jessup, in his book, Transnational Law::18

The subject to which these chapters are addressed is the law applicable to the complex interrelated world community which may be described as beginning with the individual and reaching on up to the so-called "family of nations" or "society of states." Human society in its development since the end of the feudal period has placed special emphasis on the national state, and we have not yet reached the stage of a world state. These facts must be taken into account, but the state, in whatever form, is not the only group with which we are concerned. The problems to be examined are in large part those which are usually called international, and the law to be examined consists of the rules applicable to these problems. But the term "international" is misleading since it suggests that one is concerned only with the relations of one nation (or state) to other nations (or states).19

David Cavers, in his article, "The Developing Field of International Legal Studies," ${ }^{20}$ deals at length with the drastic alteration required by the new approach to international legal studies and their place in the law school curriculum:

The new ... approach ... reflected an ... increased emphasis on the lawyer's function as planner, counselor, and negotiator and less on his role as advocate. With this shift in emphasis had also come a different attitude toward law itself, or, more specifically, toward legal doctrine..$^{21}$

Cavers illustrates the trend in interest of legal educators by the kinds of questions they are coming increasingly to ask. 'What is the law?" is yielding prim-

18 Jessup, Transnational Law (1956). Both Myres McDougal and Quincy Wright have written extenstively on the need for a broader approach to the study of international law and relations. McDougal analyzes the inadequacies of contemporary theory about international law in International Law, Power and Policy: A Contemporary Conception (1954).

19 Jessup, Transnational Law 1 (1956).

${ }^{20} 47$ Am. Pol. Sci. Rev. 1058 (1953).

$21 \mathrm{Id}$., at 1063. 
acy to "What is the problem?" and the subsequent question, "What do I do now?" And further:

A willingness to recognize these functions of the lawyer as relevant to legal education gives rise to difficulties no law school has fully solved, and the processes of change thus inspired have in the main been molecular and interstitial. However, they have been undermining the conception of a law curriculum designed by reference to "branches of the law." Individual and social problems tend to cut across the "branches." Another consequence has been a growing recognition that to give an answer to "What is the problem?" or to "What do I do?" requires that the law teacher and student take into account a wider range of phenomena than was once thought germane to their studies. Political pressures, psychological factors, business practices, sociological and economic data and theory, all are likely from time to time to become pertinent and important.

In international legal studies, these considerations have special force.... The "law" is likely to be uncertain; the range of alternatives wide; and the opportunities for resort to lawyer-made law many.... Whether he is an adviser to a government office or to a private business concern, the lawyer is likely to have a creative function to perform which will oblige him to reckon with many factors that fall outside the traditional compartments of International Law and Comparative Law. That being the case, the criteria for planning a program of instruction and research may be formulated more accurately in terms of problem areas than branches of the law.22

Nor is concern about the international content of legal studies limited to the educator. Arthur Dean has described the importance of training in international law for the practicing lawyer. It is a mistake, he says, to think that for the general practitioner a course in public international law is a luxury item rather than a staple. He expresses the hope that

the law student would be encouraged to take an international law course, not as a first step in a highly specialized program, but on the same basis as a course in contracts, trusts and estates or taxation. If he looks forward as an active practitioner to practicing exclusively public international law he may, so far as present experience goes, be doomed to disappointment. But in order to obtain a legal skill of growing utility in the context of the general practice of the law as well as to prepare for that responsible leadership in his community which lawyers are expected to provide, the law student would do well to steal a few hours from Williston, Powell and Griswold for Dickinson, Hudson or Jessup..$^{23}$

22 Id., at 1064.

${ }^{23}$ Dean, The Role of International Law in a Metropolitan Practice, 103 U. of Pa. L. Rev. 886,900 (1955). Milton Katz has described the importance of international training for lawyers entering government service or private practice. He points out that "[a]s the day to day work of government, business and agriculture in the United States is increasingly affected by the worldwide ramification of America's position, there is a corresponding effect upon the problems which make up the daily grist of the lawyer's mill." The situation in international legal studies is similar to earlier developments in such presently staple fields as administrative law, tax law, labor law, conflicts and corporations, for which at one time law courses were rare, textbooks did not exist, and students were few. 
The American Bar Association has recently undertaken a World Peace Through Law program to stimulate interest among practitioners in the United States and abroad in promoting the rule of law in international relations and to advance the use of legal and judicial means in the settlement of international disputes.

\section{III}

The range and content of potential law school activities needed to encompass fully the study of problems just outlined are obviously staggering. Law schools must be sensible in what they embrace in their teaching and research activities. Yet to be sensible means also to be reasonably adequate to handle the problems at hand, and this may require undertakings of a revolutionary character in legal education.

To bring international legal studies into the mainstream of American legal education is not a simple process. At least four processes are involved. The first and most obvious of these concerns the place of international studies in the education of an American law student. His understanding of law must be enriched and his techniques enlarged through drawing on the experience of other legal systems, foreign and international. The second process is research on the vast array of new problems that confront not only the law teacher, but the government policy-maker and the businessman as well; there is involved here the familiar but perplexing dual task of enlarging the area of knowledge needed for practical understanding and action, and systematizing knowledge needed for teaching. The third process concerns the contribution which American legal experience can make to other countries: the teaching of foreign students in American law schools and cooperation with foreign law schools and lawyers in helping them to solve their problems of legal policy, practice and education. A fourth process, to which all the others contribute, is the development of a wider, more universal view of the role of law in society, through the collaboration of lawyers of differing nationalities towards the advancement of an international order.

There are some very real rigidities, even among the larger university law schools, which stand in the way of an adequate handling of international studies. Among these are such familiar yet thorny problems as crowded curricula, achieving a balance between training law students in principles and developing the tools of their vocation, establishing a corps of "international specialists" while involving as many members of the faculty as possible in international studies, the lack of a tradition and of finances for doing other than book research, the lack of an accepted pattern for engaging research personnel as contrasted with teaching personnel, the isolation of the law faculty from other university faculties, the stubborn lack of interest in legal systems outside of Western Europe and North America, and the absence of international questions on the bar examinations. Experience to date suggests that lack of student interest need not be a major obstacle. Large numbers of students and the best students 
will respond when the school faculty, from whom leadership now is coming, ${ }^{24}$ have removed some of the foregoing obstacles to their own research and teaching efforts.

What guides should the law schools follow in fulfilling and setting limits on their tasks? President Pusey of Harvard has, in a more general context, provided one basic guide. He did so in response to an exhaustive questionnaire concerning activities in international education which the American Council on Education sent to its member institutions following President Eisenhower's urging that American universities help in the development of educational institutions in the underdeveloped countries of the world. President Pusey in his reply said in part:

Actually, five of your six reasons for encouraging international education seem to me good reasons. But do they not pass by entirely the main function of all educationinternational or otherwise? Should not the primary function of an educational institution be to determine the intellectual potential of available candidates for study and then to educate individuals to their full capacities?

Does it matter that Aristotle was a Greek, Averroes a Spanish Arab, Comenius a Czech, Galileo an Italian, or Leeuwenhoek a Netherlander? They all "advanced learning" and "helped perpetuate it to posterity" (thus citing a couple of phrases out of Harvard's own traditions). By these tokens they would have all been welcomed as graduate students or research fellows, and they might even have qualified for scholarship aid. As alumni of any American university, such men would doubtless have encouraged understanding among nations, developed the economic and social structures of their respective countries, added to the world's cultural resources, etc., etc. I think we educators can all agree on the advantages of a free trade in ideas and a free exchange of scholars in a world now unhappily divided. ${ }^{25}$

There is a second, and closely related, guide for the law school which is part of a university. If the lawyer's task in the advancement, organization and transmission of knowledge in international studies is gigantic, it is no more so than the tasks of, say, the economist and the political scientist. Indeed, the most important problems require attack by several of the professions and disciplines, cooperatively and separately. Progress in cooperation need not mean only "group" or "programmed" or "inter-disciplinary" research or that every lawyer must become also an amateur economist, political scientist, historian,

${ }^{24}$ Jessup, op. cit. supra note 17, chides the Supreme Court for "the current fashion of jurisprudential theory" which alone prevents it from resuming its leading role in pronouncing on questions of international law; he also chides the Departments of State and Justice for not undertaking to disabuse the Court of its "wholly unreal notions ... about the relation of its decisions to the conduct of the diplomatic relations of the United States." Nor has the bar, with notable exceptions, exhibited sustained leadership or interest; encouraging developments, however, are the meeting of the American and British bars in London, the project of the American Law Institute to prepare a Restatement of the Foreign Relations Law of the United States, and the American Bar Association's World Peace Through Law program.

${ }^{25}$ Letter of President Pusey to President Arthur Adams of the American Council on Education, January $29,1957$. 
anthropologist and linguist. There is need also for individual research and for maintaining the distinctive approach and point of view and tools of the lawyer.

If cooperation with his university colleagues outside the law school is a sound principle for the law professor engaged in international studies, so too is cooperation with his colleagues in other law schools. Although highly competitive relationships among law schools may have their place and advantages, they constitute an obstacle to the sensible cooperation among law professors that is essential on a nation-wide basis if the urgent tasks of international education are to be performed with adequate manpower and brainpower.

In what follows I shall describe a few of the recent programs developed and problems encountered by American law schools in the pursuit of their functions -inevitably overlapping - of teaching, research and international education. ${ }^{26}$

Teaching. - What should be taught in order to give interested students a working grasp of the legal aspects of international problems? This question is not simply one of choosing from among existing courses and giving greater attention to the "international" courses. It is a question, rather, that presents to law professors a wide range of problems in the organization and transmission of knowledge. New courses and the teaching materials for them have to be created; old courses have to be illumined by new materials. These tasks in turn require the development of a new intellectual framework and approach that enable professor and student alike to embrace important international problems of sufficient complexity within an organized curriculum of reasonable simplicity. In the characteristically pluralistic and pragmatic fashion of American education, the law schools have gone their several ways-proceeding not from theoretical doctrine but from the closer and more comprehensive study of the problems that seem to have the importance and relevance to warrant treatment in the law school.

In the spring of 1958 faculty members from ten law schools met informally to exchange information about the approach each was developing to the teaching of international legal studies. The fact that the meeting took place was itself significant evidence of an encouraging spirit of intellectual cooperation. No single pattern emerged or was expected. The problem of the small school which might envisage one course in international studies was distinguished from the large university law school which may present a wide variety of introductory, advanced and seminar courses. Nevertheless, certain trends were discernible.

Considerable interest was shown in the development of an introductory

${ }^{26}$ It will be evident that the developments mentioned have less immediate relevance to "local" or those "national" law schools which deal only or primarily with state and federal law. Such schools will, however, ultimately also be affected by the interest in international studies as an integral part of American legal education. In response to the general interest in international legal studies, the Ford Foundation recently inaugurated, primarily at non-grant schools, an experimental program of fellowships to enable law faculty members, following a series of ten-year grants to fourteen of the major law schools, to undertake research and study that will enrich their teaching in the field of international studies. 
course that could serve both as the only course for students planning no further work in the field and as preparation for students who would then proceed to more advanced courses in international law and organization, comparative law, and the legal problems of international business and economic development. A course of this nature might also help solve the problem of teaching international legal studies at the small school.

Harvard Law School offered such a course, called The Law of International Transactions and Relations, for the first time in 1958-59. The course examines transactions and relations which extend to more than one country, identifying those aspects which exist only because of the international factor or the factor of "foreignness," i.e., only because more than one country is involved. The first part of the course surveys a typical range of transactions such as entry into and residence within a foreign country, the acquisition and use of property and employment in a foreign country, doing business abroad in its various aspects, dealing with enterprises in which foreign governments have a substantial interest, and problems of foreign exchange. The second part concerns the reach of one legal system into others, and considers the legal aspects of overlapping or conflicting taxation and regulation and problems of nationalization and expropriation. The pattern of analysis adopted in the course is that of the American lawyer who thinks simultaneously and continuously in terms of several legal systems (states and federal), but projects this experience onto an international plane where lawyers must think in terms of three legal systems: of the home country, of the foreign country, and of public international law. An effort is made throughout to enable the American student to appraise the relevance of international law to his professional task and to develop a pertinent sense of lawyership.

Another trend appears to be the introduction of courses on doing business abroad, including antitrust and taxation problems, which Columbia Law School was among the first to adopt many years ago.

At the same time, considerable experimentation is underway with the traditional course in International Law. ${ }^{27} \mathrm{~A}$ large part of this course has been concerned with constitutional problems, just as early courses in taxation less than a generation ago dealt largely with constitutional aspects of the subject. Special courses have been offered, as at Columbia, in the constitution and foreign affairs, and the problem has been discussed, for example, at Stanford, of how to deal more adequately with these aspects in the regular course on U.S. constitutional law. Also, remodelling of the standard international law course has been attempted in order to accommodate the teaching of conflict of laws, as at Northwestern, ${ }^{28}$ and the teaching of comparative constitutional law and com-

${ }^{27}$ For the situation prevailing in 1953 see Bishop, International Law in American Law Schools Today, 47 Am. J. Int. Law 686 (1953).

${ }^{28}$ MacChesney, The Teaching of International Law and Conflicts as One Course, $11 \mathrm{~J}$. Legal Ed. 55 (1958). 
parative federalism. Moreover, widespread attention is being given to bringing international, especially comparative, materials into the regular courses in domestic U.S. law.

At Stanford an interesting experiment is underway in the teaching of the constitutional law of India, in which many American students, in studying India's different way of protecting civil rights, gain insights into civil rights in American law which they did not get from their course in the U.S. constitution.

The presence of increasing numbers of foreign students in the law school, discussed more fully below, can, if properly used, have considerable educational benefits for American students. Confrontation of American and foreign students in the discussion of how the same problems are handled under their different legal systems provides a comparative illumination of the laws of each.

As noted above lack of interest among the students in international studies appears to be less of an obstacle than faculty attitudes and course scheduling. For example, at Michigan, where international courses are included among a group of courses from which an election must be made, about 85 per cent of all law students receive some formal training in international legal studies. At Harvard, which has no requirement in international courses, over 150 students have enrolled in the new introductory course and over 40 per cent of all students enroll in one or more international courses before graduation.

It is possible but not altogether proved that in some other schools the pressure of preparation for the bar exam, which contains no international questions, keeps down student enrollment in international courses. An ingenious experiment has been tried at Berkeley during the past five years of holding a workshop in international studies between graduation and the time when study for the bar exam begins in earnest. Freed of the pressure of credit and bar exam, students participating in the workshop appear to benefit from a concentrated period of study of international problems. The experiment has also attracted the interest of more teachers from other schools around the country than can be admitted to the workshop.

The topic of teaching international studies should not be closed without a word about the relevance of the broader thinking that is taking place concerning the place of law studies in the undergraduate college curriculum. As law teaching and law schools have become highly professionalized, the law content has been wholly squeezed out of the curriculum of a liberal arts college education. The words of Paul Freund, in his excellent article, "Law and the Universities," ${ }^{29}$ are not less relevant to international legal studies than to law more generally:

My theme is ... the contribution that law can make to general education. Instead of concentration on the content of pre-legal studies for lawyers, I suggest that some thought be given to the legal content of non-legal studies. The universities are ex-

${ }^{29}$ Freund, Law and the Universities [1953] Wash. U. L. Q. 367. 
perimenting successfully with courses on science for the citizen, aimed at an appreciation of scientific method or the tactics and strategy of science; courses have been introduced on economics for the citizen (known affectionately in some places as "economics for the idiot"); and similarly, in the name of general education, studies have been encouraged in the history of the pervasive problems of political thought. Yet, so far as I am aware, almost no effort has been made to provide the general student with an introduction to an understanding of the legal order. The neglect is all the more striking when we remember that the institutions which are central to our civilizationsecurity of the person, freedom of the mind, ownership, and the intercourse of tradeand which at the same time are the substance of our daily living, are all dependent on a structure of law. Should the student, whose preparation for mature living must include a study of Boyle's Law of gases, be left unexposed to Pound's Spirit of the Common Law and Cardozo's Nature of the Judicial Process? ${ }^{30}$

Research.-No aspect of law school activity has been the target of more selfcriticism than law school research, or, rather, the lack of it. It is increasingly the subject of articles and law school deans' reports. Thus, Dean Griswold of Harvard, dealing with research in his report for 1957-58, says:

[L]aw schools generally have not been notably successful in opening up new fields for research activities and new methods for their pursuit. In this, law teachers have lagged far behind their fellows working in the fields of the natural sciences, including medicine, and well behind many of those working in other areas of the social sciences. ${ }^{31}$

He concludes:

What is needed is a substantial fund for unrestricted research purposes . . . which would provide the means for (1) freeing faculty members to engage in full-time research work when they might want the opportunity, and (2) enlisting and training men of high caliber for research to work with Faculty members on occasion, or to undertake special investigations under the general direction of the Faculty. ${ }^{32}$

Yet there are rigidities other than lack of funds that provide obstacles to research. Some mentioned by Dean Griswold stem primarily from law school emphasis on teaching and preparation of teaching materials; these rigidities are of a professional and administrative nature and therefore potentially within the capacity of the faculty and administration to remedy even without funds.

James Willard Hurst in his article, "Research Responsibilities of University Law Schools," has made a long and searching indictment of law school research. ${ }^{33}$ Hurst attacks the absence of an adequate research policy and says that "little that can be dignified as a philosophy for research has emerged in

${ }^{30}$ Id., at 367-68.

${ }^{31}$ Harvard Law School, Dean's Report 1957-58 at 11.

32 Id., at 15.

${ }^{33}$ Hurst, Research Responsibilities of University Law Schools, 10 J. Legal Ed. 147 (1957). See also Yntema, Comparative Legal Studies and the Mission of the American Law School, 17 La. L. Rev. 538 (1957), and Yntema, Comparative Legal Research, 54 Mich. L. Rev. 899 (1956). 
the American law school world." After making a number of constructive suggestions he concludes:

The law school world today seems, on the whole, a distressingly complacent and limited world. It may be said to its credit that this is not a fat and sluggish complacency. There is lively, stimulating tough-mindedness in legal instruction in good law schools; a well-taught first year of law still offers men the most provocative educational experience in the American system. But there is too much of the self-centered and narrow business of the technician and too little of the curiosity of the philosopher in the temper of the law schools. This condition does not fit well with mounting challenges to legal order. Both cause and cure lie in the state of legal research. The strategy most likely to bring fresh vigor and resources into the university law schools would be, for at least ten years to come, to assign a preferred position in their programs to promotion of basic research into the nature, functions, and working realities of legal order..$^{34}$

In the field of international studies the considerations illustrated by the references to Griswold and Hurst have special validity. The enormous scope of international activities, the vast complexities encountered in their study, and the added costs of international travel and collaboration raise these research considerations almost to another level or order. The presence of an adequate policy for determining the purposes, choice and administration of research becomes doubly important. One may point to situations where the presence of research funds was not accompanied by vital research. One may ask whether some of the many professorships devoted to the teaching of numerous specialties of domestic law might not be better dedicated to research. In saying this I do not mean to discount the need for research funds or the importance which funds sometimes have in catalyzing a change in established patterns. Rather, I am in agreement with the need expressed for the development by law schools of more adequate research policies.

If research policy has lagged generally, there are not lacking particular examples of research that have been successful in broadening and diversifying the contribution of the law schools to knowledge and to the application of knowledge in the improvement of the law. One such example is the International Program in Taxation which the Harvard Law School has carried out in cooperation with the United Nations over a six year period. Several things have been accomplished simultaneously. The tax laws and the system for administering those laws in a number of countries have been studied and recorded in a manner permitting comparisons; eighty-one tax officials from thirty-five countries have been trained in tax administration; and new courses have been developed to enrich the curriculum for law students. The Program has a potential influence on policies and practices in an area of public finance that is of vital importance in economic development. Another example is the study being carried out at Columbia into the actual workings in a number of countries of

${ }^{34}$ Hurst, op. cit. supra note 33, at 161. 
international joint business enterprises as a means of doing business in and promoting the development of foreign countries.

Characteristic of the examples cited is an emphasis not upon the question, "What is the law?" but on the question, "What is the problem?" Such research, it is clear, is the domain not of the international specialist alone, but of all law faculty members.

Another characteristic of the research examples given is cooperation by law faculty members with non-lawyers in order to achieve a fuller understanding of the many dimensions of the problem that a legal approach alone can provide. If law school research lags, perhaps it is in part because lawyers have tended not to engage in intellectual cooperation with their university colleagues to the same extent as some of their social science colleagues-although collaboration across school and disciplinary lines anywhere is still as much the exception as the rule. Nor have lawyers, in the field of international studies, tended to collaborate with their colleagues overseas to the same extent as some of their social science colleagues. Unlimited opportunities for promising research by lawyers would appear to be at hand within the broader university context of "foreign area studies" of the non-Western world, studies of law and the legal order as part of the broader concerns for public management of development programs in the underdeveloped areas, and studies of international relations and U.S. foreign policy.

Perhaps it is time to ask whether the question, what is the problem, does not need to be supplemented more frequently with the subsequent question, what are the issues affecting policy? It strikes me that the lawyer's contribution to research that is policy-oriented falls far short of its potential. ${ }^{35}$ Basic research on problems that will produce data and knowledge is vitally important. But equally important is that research of a different character which, drawing on the relevant knowledge, helps in the formulation of policies on which to base action. The universities have a multiple role as centers of private research on matters of policy: they can be centers for the independent appraisal and criticism of official policy, they can help in the training of governmental policy makers, and they can contribute to the general education.

The lawyer's training and experience fit him especially well for the tasks of translating knowledge into responsible action, of choosing among contingent alternative courses of action, of guiding action through the formulation of policy and law, of institution building. The research approach of the lawyer cannot be that of the physical scientist nor even that of the social scientist. The scientist proceeds on assumptions (tested by experience) that the world is

${ }^{35}$ Reference has already been made to the substantial policy results achieved in the Harvard International Program in Taxation. But the role of law in economic development and foreign policy is little recognized. For example, a two-day conference of representatives of the leading American research centers in the field of international relations was recently convened by the Carnegie Endowment for International Peace, covering such subjects as the implications of economic, political and technological trends for research. In the lively discussion of policyoriented research, the place of law and lawyers was scarcely mentioned. 
ordered, that this order is to be discovered by him, and that from his observations and controlled experiments he can draw generalizations that have universal validity. The lawyer, in contrast, proceeds on assumptions that order has to be created, that the contingency of alternative potential orders has to be resolved through action based on responsible judgment, and that this requires the participation and active collaboration of those among whom relations are to be ordered.

International education.-The foregoing considerations concerning teaching and research by American law schools lead to the subject of collaboration among lawyers of different countries. Teaching or research that involves lawyers of different nationalities, which are treated here as international education, is one illustration of the interaction of different legal systems through the medium of education.

As President Pusey implied in the quotation above, ${ }^{36}$ a law school professor is both a lawyer and a teacher. He has the responsibility and opportunity to promote the important relation between law and education on which the rule of law ultimately depends. In a narrow sense, this might mean, for example, assistance in the improvement of legal education in the underdeveloped countries. In a broader sense, it means communicating the understanding that our legal institutions are themselves an exhibition of education, of what Lon Fuller has termed "the collaborative articulation of shared purposes." 37 In the words of Paul Freund:

It was a philosopher, Alexander Meiklejohn, who best expressed the educational role of the Supreme Court, a role which I believe is played by our legal institutions as a whole, and who stressed the closeness of the work of the Court to the proving-ground of experience:

"In the American schools and colleges, thousands of men and women are devoting their lives to the attempt to lead their pupils into active and intelligent sharing in the activities of self-government. And to us who labor at that task of educating Americans it becomes, year by year, more evident that the Supreme Court has a large part to play in our national teaching. That court is commissioned to interpret to us our own purposes, our own meanings. To a self-governing community it must make clear what, in actual practice, self-governing is. And its teaching has peculiar importance because it interprets principles of fact and of value, not merely in the abstract, but also in their bearing upon the concrete, immediate problems which are, at any given moment, puzzling and dividing us. But it is just those problems with which any vital system of education is concerned." 38

To the extent that American lawyers are exclusively preoccupied with domestic law and indifferent to the important role of law and the legal

\footnotetext{
${ }^{35}$ See text at note 25 supra.

${ }^{37}$ Fuller, Human Purpose and Natural Law, 3 Natural Law Forum 73 (1958).

${ }^{38}$ Freund, op. cit. supra note 29 , at 378.
} 
professions in other countries, they ignore opportunities to promote and widen the rule of law. In Asia and Africa the common law and civil law traditions of a free society are competing with the communist view of law. Free India and communist China furnish a dramatic illustration of such competition. The Indian lawyer can play an important role as a stabilizing force in his society as someone who has respect for the rule of law and yet understands the place of law in change, in reform, in the protection of human rights and in the programs of a welfare state. The underdeveloped and newly independent countries present something of a paradox. In their avid desire to catch up with the West technologically they emphasize technical training and development. All too easily they neglect the need for continued training in and development of the political and legal traditions of freedom through which their independence came about and must be maintained.

A number of cooperative projects involving American and foreign law schools combine both training and the opportunity for research. Harvard, Michigan and Stanford Law Schools, six Japanese law schools and the Legal Training and Research Institute in Japan have been cooperating in a project, now in its fifth year, that has had appreciable influence in Japan and upon the participating American lawyers. ${ }^{39}$ Columbia and Michigan Law Schools are similarly cooperating successfully with the law faculty of the University of Istanbul. The California Law School and the Institute for Conflict of Laws and Foreign Private Law of Cologne University are engaged in a cooperative research and training program. India has established a Law Institute ${ }^{40}$ that is engaged in promoting research on important problems of Indian administrative and constitutional law, with the assistance of American and other foreign lawyers. In Burma a similar activity has begun on a more modest scale. These activities and others like them are illustrations of international education in the best traditions of American higher education. To the extent that they involve assistance to the foreign countries in the improvement of their legal education the American lawyers are serving also as educators. Such contacts with a foreign educational system and a foreign legal system are most successful when they do not attempt to export American educational and legal practices without regard to the differences in the social system in question. At their best such projects involve intelligent interdependence of teaching, research and international education, and thus provide an international illustration by a university law

${ }^{39}$ Among the interesting papers written by participants in this program are Rabinowitz, The Historical Development of the Japanese Bar, 70 Harv. L. Rev. 61 (1956), and von Mehren, Some Reflections on Japanese Law, 71 Harv. L. Rev. 1486 (1958). Walter Gelhorn, who participated in a program of American studies in Japan sponsored by the Rockefeller Foundation, prepared at Japanese request a lively memorandum suggesting some worthwhile empirical studies for Japanese lawyers, Impressions of Japanese Legal Training, 58 Col. L. Rev. 1239 (1958).

${ }^{40}$ See Ebb and Markose, Conference of the Indian Law Institute, 7 Am. J. Comp. Law 219 (1958). 
school that resembles the teaching-research-and-extension activities of the land grant colleges in their programs of service to communities in the United States.

International cooperation can make an important contribution to the training of American law students and the training of foreign law students, as well as to research. To illustrate: If the objective is to train American lawyers in the laws of a foreign country or an international organization, it is evident that the entire training cannot best be done in the United States. Some training in the foreign country or at the center of the international organization is desirable. To this end it is helpful if there are legal personnel and institutions abroad who are in a position to accelerate and facilitate the education of the American lawyer. A number of American law schools, e.g., the Universities of Chicago and California, and New York University, have worked out cooperative arrangements to give training in a foreign legal system to American law students before and after they have received their LL.B. The number of instances in which business and law firms have recruited men with such training, still very rarely possessed by American lawyers, is steadily increasing.

If the objective is to give foreign lawyers insights into American legal experience with the intention of their utilizing their education effectively on their return to their own countries, it is useful for the American law schools to have close relations with the institutions from which the foreign students come and to which they will return. This enables the American law schools to make better selections of students and to adapt their training programs more realistically to their needs.

There are over 450 foreign lawyers studying at law schools and universities in the United States. Most of these students would find an undergraduate American law degree as useless to their professional advancement in their own countries as an American lawyer intending to practice in the United States would find a degree for the practice of law in Germany, France or India. Much of the interest in our law, therefore, is on the part of foreign lawyers who have already received legal training in their own countries and desire greater understanding of legal developments in the United States. The study they engage in here is typically a kind of comparative education in which they are attempting to learn and understand American legal experience in the hope of applying it to the legal systems in their own countries.

The presence of such large numbers of foreign students in American law schools has brought with it serious scrutiny by law schools of the educational experience the students are being subjected to. The early approaches tended to ignore more or less completely the fact that the foreign law students were not being educated for the practice of law in the United States. Generally speaking, they attended the same courses as American students, and one of the better American schools required even students with a foreign law degree to enroll in the first year with entering American students (needless to say, most of them elected the Ph.D. program outside the law school). 
In recent years the leading law schools have taken a number of steps to remedy these shortcomings. Typically, special courses have been devised to introduce foreign students to American legal education and the case system of teaching, and to familiarize them with American legal and social institutions. Special language classes have been used to improve the students' English to the point where education is effective. Yet special classes for foreign students are balanced by classes with both American and foreign students, the confrontation being instructive to both.

Where the foreign student is from a common-law country he may be admitted to the undergraduate law classes, as at the University of Chicago, and be a candidate for the J.D. degree upon successful completion of one year of study. In certain schools, special degrees, such as Master of Comparative Law or Jurisprudence, have been offered. Where, as at New York University and Southern Methodist University Law Schools, there are large numbers of Latin American students, special one-year programs are given in American law; and the best students may stay on in the United States to work for advanced degrees in special fields of interest.

If the objective is to do research into foreign and international problems, it is again evident that such research is often best done in cooperation with foreign lawyers who are familiar with the foreign legal systems or views that are involved in the problems. Such cooperation is not only useful from the very practical standpoint of obtaining the essential facts and relevant laws; it is also useful from the standpoint of developing insights into the comparative study of how individual societies approach their own legal problems. Where the foreign legal system is that of a highly advanced country, the research or the training of an American lawyer is facilitated by the presence of institutions highly experienced in teaching and research. Where the foreign country is pre-industrialized and its legal institutions are not well developed or its law schools of low caliber, training and research by Americans are made a great deal more difficult. As has been learned in foreign area studies generally, it is difficult to learn about a foreign people that does not know much about itself-in the form of systematic organized knowledge, written records and statistics, and through the medium of developed institutions of higher learning. Yet the progress made in other areas of international education indicates that, in the legal aspect too, there is reason to hope for vast improvement. 